\title{
Neoplasia and paracoccidioidomycosis
}

\author{
M. A. Shikanai-Yasuda • Y. M. T. Conceição • \\ A. Kono - E. Rivitti - A. F. Campos - S. V. Campos
}

Received: 4 May 2007 / Accepted: 25 July 2007

(C) Springer Science+Business Media B.V. 2007

\begin{abstract}
Published studies on the association between cancer and paracoccidioidomycosis consist either isolated cases or clinical data based on hospital cohorts of paracoccidioidomycosis. The frequency of neoplasia in series of $\geq 80$ patients with paracoccidioidomycosis ranges from 0.16 to $14.1 \%$, mean of $3.96 \%$. There are only two retrospective controlled studies, one of them showing greater incidence of carcinoma in biopsy and necropsy samples of paracoccidioidomycosis ( 12 cases in 147 patients with the mycosis: $8.2 \%$ ) than in the necropsies of the control group (320 cases in 7,302 necropsies: $4.9 \%$ ). In the other, 22,409 autopsies were reviewed and 4,372 cases of cancer were found; of the 85 patients with paracoccidioidomycosis, 12 were diagnosed with cancer. No differences were observed in the
\end{abstract}

M. A Shikanai-Yasuda ( $₫)$

Infectious and Parasitic Disease Department, Laboratório de Investigação Médica em Imunologia do, Hospital das Clínicas, Faculdade de Medicina da Universidade de São Paulo, Av. Enéias de Carvalho Aguiar, 500 CEP 05403 000, São Paula, Brasil

e-mails: dmip.shikanai@hcnet.usp.br,

lim48imuno@yahoo.com.br

Y. M. T. Conceição

Infectious and Parasitic Disease Department,

Faculdade de Medicina da Universidade de São Paulo, Universidade Federal do Mato Grosso, Mato Grosso, Brazil frequency of malignancies between the group of patients with paracoccidioidomycosis (14.1\%) and the control group (19.5\%). Considering all the reported cases, carcinoma was more frequent than hematological malignancies, and was more often found at the same site or in a neighboring site affected by the mycosis, usually occurring after the diagnosis of the mycosis. Commonly, the basic cause of death was related to secondary infections or neoplasia. Lymphoma was associated with poorly organized rich in fungi granuloma. The clinical course and mortality were related to the cancer evolution or secondary infections and was worse in lymphoid series, metastatic carcinoma or in patients under cytotoxic chemotherapy. Additionally, as in several cases the clinical and histopathological data

\footnotetext{
A. Kono

Infectious and Parasitic Disease Clinics, Hospital das Clínicas, Faculdade de Medicina da Universidade de São Paulo, Av. Enéias de Carvalho Aguiar, 255 CEP 05403 000, São Paulo, Brasil

E. Rivitti

Infectious and Parasitic Disease Clinics, Hospital das Clínicas, Dermatology Department, Faculdade de Medicina da Universidade de São Paulo, Av. Enéias de Carvalho Aguiar, 255 CEP 05403 000, São Paulo, Brasil

A. F. Campos - S. V. Campos

Infectious and Parasitic Disease Department, Faculdade de Medicina da Universidade de São Paulo, Av. Enéias de Carvalho Aguiar, 500 CEP 05403 000, São Paulo, Brasil
} 
may mimick neoplasia, the correct diagnosis of both diseases is essential to guarantee an early and safe intervention.

Keywords Paracoccidioidomycosis - Cancer .

Neoplasia · Lymphoma · Leukemia · Carcinoma

\section{Introduction}

The association between cancer and paracoccidiodomycosis has been established since 1933 [1]. In fact, the incidence of the malignancy may be attributed to the dysfunction of cell immunity in the active paracoccidioidomycosis. The acute and multifocal chronic presentation of this mycosis have been associated to transitory hypo-reactivity to $P$. brasiliensis antigens and to TH2 type immune response, characterized by IL4, IL10 cytokines secretion, low IF $\gamma$ secretion [2], deficiency in the killing activity of macrophages and natural killer cells [3]. Continuous stimulation of epithelial cells and phagocytic mononuclear system by fungal antigens might predispose these cells to malignant transformation and surveillance against malignancy might be affected. In parallel, granulomatous inflammation and pseudoepitheliomatous hyperplasia observed in this chronic disease mimic well-differentiated malignancy [4], predisposing to incorrect diagnosis of cancer instead of paracoccidioidomycosis.

\section{Cancer or paracoccidioidomycosis?}

Many reports have focused on the similarities between malignancy and paracoccidioidomycosis based on clinical manifestations like lymphoma or leukemia or primary malignancy of the biliary tract [5] in the acute/subacute form of this mycosis. Other carcinoma diagnoses-instead of this mycotic lesions-were reported, such as colon cancer in case of intestinal involvement [6], laryngeal or intra-oral carcinoma, in the oral and laryngeal involvement by this mycosis $[7,8]$ and posterior fossa tumor in cases of cerebral paracoccidioidomycosis [9, 10]. Misdiagnosis of cancer have often caused severe consequences in patientś life and their relationship with their families and community, so clinicians need to be aware of the differential diagnosis of such diseases. Both diseases may occur concomitantly and biopsies should be requested to establish the correct diagnosis as soon as possible.

Citology has also been useful in the diagnosis of squamous cell cancer, presenting sensitivity of $86.5 \%$, accuracy of $89.6 \%$, predictive positive value of $95.7 \%$, and specificity of $94.3 \%$ [11].

More recently, immunohistochemical expression of some tumor markers was analyzed in the granulomatous inflammation and pseudo-epitheliomatous hyperplasia. P53 was absent in normal cells and paracoccidioidomycosis inflammatory granuloma, in contrast to neoplastic lesions [12].

Moreover, cytokeratins expression was analyzed during inflammatory processes, with the objective of describing differences between cancer and mycotic lesions, concerning these filament of epithelial cells expression during the processes [4]. In oral lesions of 28 paracoccidioidomycosis patients and in the mucosa of healthy control individuals, CK1, CK10, CK14, CK6 and CK16 were not found. In contrast, the latter three cytokeratins were expressed in the basal layer of the epithelium of cancer lesions.

\section{Cancer and paracoccidioidomycosis}

Most published studies consisted either of single case reports or clinical and epidemiological data collected from hospital-based cohorts of patients with paracoccidioidomycosis [13-38]. Only two studies analyzed the relationship between cancer and paracoccidiodomycosis [13-14].

\section{Retrospective controlled studies}

In the first study, published in 1980, Leão \& Mendes included necropsies and biopsies from Faculdade de Medicina da Universidade de São Paulo and found 12 patients with cancer (8.2\%) among 147 paracoccidioidomycosis patients, as well as 360 carcinomas in 7302 necropsies $(4.2 \%)$ in the control group [13]. The authors considered this difference significant (Yule coefficient) and suggested higher incidence of cancer in paracoccidiodomycosis patients than in the control group. A total of 11 out of such 12 malignancy lesions were carcinoma, 6 of them were located in the 
same area of the mycosis: one lymphoma, one stomach carcinoma, two lung metastases of carcinoma and two prostate adenocarcinoma. The authors did not comment on the inclusion criteria of cases and controls, the period of study, the absence of biopsy control group, the description of malignancy in the same area of mycosis, clinical forms of mycosis, temporal relationship between both diseases, and activity of mycosis at the time of the cancer diagnosis.

In the second controlled study, Conceição, 1996, analyzed the incidence of cancer cases during an 18-year period (1974-1991) in a retrospective study of autopsy records in Faculdade de Medicina da Universidade de São Paulo, both in the group of patients with paracoccidioidomycosis and in the general autopsy record group [14]. The mycosis was diagnosed based on mycological and/or serologic and/or histopathologic exams. The following variables were observed: sex, clinical manifestations, age, anatomic location, and histopathology of malignancies, time interval between the diagnosis of both diseases, and cause of death. Children under 14 years and HIV-infected patients were excluded. A total of 12 cases of cancer were registered among 85 paracoccidioidomycosis patients $(14.1 \%)$ and 4,372 cancer cases among 22,409 cases of necropsies (19.5\%). No statistically significant difference was found in the frequency of malignancies between paracoccidioidomycosis and control group of necropsies (chi square test, $P=0.26$ ). Malignancies associated with the mycosis presented a gender distribution similar to that observed in control group. Most malignancies occurred in patients over 44 years in both groups. Lung cancer and hematological malignancies were predominant both in the control group of necropsies (11\% and $21.3 \%$, respectively) and in the paracoccidioidomycosis group $(41.7 \%$ and $25 \%$, respectively).

Considering only lung cancer, it was more frequent in the mycosis group than in the control group $(P<0.05)$, two out of five of paracoccidioidomycosis patients with lung carcinoma were smokers. Given that it was a retrospective study, information about smoking and other variables were not reliable, final analysis was not conclusive and its result needs to be considered in a prospective study. In the control group, lung cancer was the second more frequent for men and the fourth for women; the most frequent cancer for both sexes was leukemia/lymphomas.

Histology showed three patients with hematological malignancies: Acute myeloid leukemia, chronic lymphoid leukemia and Hodgkin lymphoma, and nine patients with carcinoma: Digestive tract carcinoma, oat cells lung carcinoma-two cases, esophagus epidermoid carcinoma, lung carcinoma, bronchus carcinoma, adenocarcinoma, of the lung and adenocarcinoma of the prostate, rhinopharyngeal carcinoma.

A total of 7 out of these 12 cancer associated paracoccidioidomycosis cases presented the mycosis 6-96 months before the diagnosis of cancer. In four of them, cancer diagnosis was made from 1 to 60 months before the diagnosis of mycosis. Active mycosis was found in 10 out of 12 cases.

Considering the presence of cancer at the same anatomic site of mycosis, five patients presented both carcinoma and paracoccidiodomycosis in the lungs and one also presented chronic lymphoid leukemia and lymph node and epiglottis involvement. One unexpected result was the low frequency of severity or dissemination of the mycosis only in two cases: one with acute myeloid leukemia under chemotherapy and one with lung carcinoma. In most cases of this study, paracoccidiodomycosis was not regarded as a determinant factor leading to mortality. Death was more frequently related to infections as immediate causes and malignancy as the basic cause.

\section{Hematological and solid organ malignancies}

Regarding case reports, Rabello Filho first described the association of paracoccidioidomycosis and superior lip epithelioma in 1933 [1].

The first association with a hematological malignancy was registered by Lacaz et al, 1948, in a 34-year-old patient with adenomegaly, oral and laryngeal mucosa lesions, anemia, hypoproteinemia, lung condensation, whose sputum and mycologic exam of oral mucosal lesion identified Paracoccidioides brasiliensis [15]. Although treatment with sulfadiazine was introduced, the patient died 11 months after the diagnosis, and disseminated exsudative lesions containing fungal forms were described in the amygdales, larynx, and liver. Hodgkin lymphoma was found in the lung, spleen and lymph nodes. A second case of this association was 
registered in 1960 in a chronic-form patient with 49 years, referring oral lesions 16 years before. The patient presented Thorax R-X abnormalities and the hypothesis of tuberculosis was not confirmed 8 and 15 years later, when the diagnosis of paracoccidioidomycosis was made. Biopsy of axilar lymph-node was performed, because the patient did not improve after having received amphotericin B (800 mg) and sulfamides, and revealed the presence of lymphoma.

Two more cases of Hodgkin lymphoma association were described by Alterio \& Del Negro, 1960, and Severo, 1980 in 49-and 44-year-old patients with lung involvement and chronic form of the mycosis $[16,17]$. The diagnosis of malignancy was made in the first case after axilar lymph node biopsy because no improvement was observed after receiving amphotericin B (800 mg) and sulfamides, presenting fever, anemia, adenomegaly and splenomegaly.

In Argentine, 1957, Gonzalez described the first association of carcinoma (lung) and paracoccidioidomycosis of hand and thorax skin [18]. Although skin lesions improved after sulfa treatment, a biopsy was indicated considering the persistence of pulmonary signals and symptoms (blood, sputum), revealing the presence of carcinoma without fungal lesions in the site of biopsies.

Nine non-controlled studies reported a series of cases collected on hospital-based cohorts of patients with paracoccidioidomycosis (Table 1).

Machado Filho \& Miranda, 1961, Brazil, described six cases of carcinoma (1.52\%) among 394 patients with paracoccidioidomycosis: three lung, one bladder, one penis and one adrenal carcinoma, two of them diagnosed at the same time of the mycosis, three after the mycosis and one before the mycosis [19]. The immediate case of death was malignancy in five out of six patients.

In 1971, Padilha-Gonçalves, Brazil described one patient with basocelular epithelioma and chronic form of the mycosis with oral, lymph node, and lung involvement among 130 patients with paracoccidioidomycosis [20].

In a series of 471 paracoccidioidomycosis cases, Rapopport et al. 1974, Brazil, reported 10 cancer patients $(2.12 \%)$ : eight of spinocelular and two of basocelular carcinoma [21]. Most of them were diagnosed simultaneously and only in one case, the anatomic site was the same for the cancer and the mycosis.

Rizzon et al. described in Brazil, 1980, two cases of lung malignancies in 82 patients of paracoccidioidomycosis: one in a patient with disseminated form and another in a patient with primary complex of paracoccidioidomycosis [22].

In Ecuador, 1983, Ronquillo et al. registered two cases of cancer among 133 patients with paracoccidioidomycosis: one with esophagus epidermoid carcinoma and the other with oral epidermoid carcinoma, associated with tuberculosis and histoplasmosis [23].

Gonçalves et al. 1984, Brazil, reported seven carcinoma cases among 81 patients with paracoccidioidomycosis: two in the larynx, two in the stomach, one in the tongue, one in the intestine, one in the parathyroid [24].

In 1992, Valle et al. Brazil, observed two lung carcinoma among 159 patients initially examined by Thorax R-X [25] and Tiraboshi et al. Argentine, described three cancers among 20 patients with paracoccidioidomycosis: two lung carcinoma and one larynx carcinoma [26].
Table 1 Frequency of neoplasia associated with paracoccidioidomycosis in cohorts based on hospital collections

\begin{tabular}{llcl}
\hline $\begin{array}{l}\text { Number of patients } \\
\text { with Paracoccidioidomycosis }\end{array}$ & \multicolumn{2}{l}{ Number of Patients with } & $\%$, Reference \\
\cline { 2 - 3 } & Carcinoma & Hematological cancer & \\
\hline 0343 & 06 & 0 & $1.75[19]$ \\
0130 & 01 & 0 & $0.16[20]$ \\
0471 & 10 & 0 & $2.12[21]$ \\
0147 & 12 & 01 & $8.16[13]^{\mathrm{a}}$ \\
0133 & 02 & 0 & $1.50[23]$ \\
0081 & 07 & 0 & $8.75[24]$ \\
0084 & 09 & 03 & $14.1[14]^{\mathrm{b}}$ \\
0405 & 18 & 03 & $5.18[27]$ \\
1794 & 64 & 07 & 3.96 \\
\hline
\end{tabular}


More recently, Campos et al. 2007 reported 21 cases of neoplasia among 405 paracoccidioidomycosis patients from Hospital das Clínicas da Faculdade de Medicina da Universidade de São Paulo in the period of 1966-2000 [27]. Eight were diagnosed at the first visit to the hospital $(8 / 405=0.02 \%)$. In thirteen $(62 \%)$, neoplasia was diagnosed 9-408 months after the diagnosis of the mycosis (median $=92$ months). In nine patients (42.8\%), the diagnosis of cancer was coincident with the reactivation of the mycosis in the same site of first fungal infection. A total of $11(52.4 \%)$ presented the neoplasia in the same organ of mycotic lesion. Leukemia, lymphoma and lymph node adenoma were observed in 19-20-and 41-years old patients, two males and one female with acute/subacute presentation of paracoccidioidomycosis. Carcinoma were observed in 18 patients, 17 males and one female, from 31 to 71 years of age, with chronic presentation of the mycosis, five in the lungs, three in the esophagus, two in each one of these sites: tongue, lymph node and skin, and one in each one of these sites: stomach, appendix, bladder and cornea. Death was registered in four cases and was caused by malignancy.

Other 23 single reports or series reports, one from Mexico, one from Argentina, and the others from Brazil, only described cases presenting malignancy and mycosis without references to the total number of patients observed in these cohorts of paracoccidioidomycosis [28-38]. One case of lung carcinoma, one of them in a patient receiving chemotherapy (oat cell carcinoma) and presenting Strongyloides stercoralis in the sputum, whose pulmonary biopsy showed oat cell carcinoma and the necropsy, large necrotic areas and bizarre forms of the fungi [28]. Association of esophagus carcinoma and chagasic megaesophagus and megaduodenum and mycosis was registered in a patient with 57 years of age [31]. Lung carcinoma and paracoccidioidomycosis were described in a male patient whose diagnosis was made by cytological examination of sputum [11]. Two patients with chronic paracoccidioidomycosis (63 and 56 years of age), the first with lung carcinoma and tuberculosis and the other with tongue and amigdala carcinoma presenting malignancies and mycotic lesions in the same organ were cured after sulfamide treatment. In the latter, late skin hypersensitivity tests to ubiquitous antigens and lymphoblastic transformation to phytohemaglutinin were negative [33]. Seven cases of lung paracoccidiodomycosis and seven cases of disseminated form were reported as associated to malignancies, $64 \%$ were represented by bronchus carcinoma, followed by skin, kidney, bladder, esophagus and lymph-node carcinoma. In $50 \%$ of the cases, the first diagnosed disease was the mycosis and tuberculosis was present in 4 of them; favorable evolution was registered in $43 \%$ of them. Three more cancer cases presenting malignancy and mycotic lesions in the same organ (oral mucosa and in larynx) were described [36, 38]. Squamous cell carcinoma of the lung was described in a patient with oral mycotic lesions, whose diagnosis was made lately after lack of improvement with antifungal treatment [37].

\section{Hematological malignancies and paracoccidioidomycosis}

Hematological malignancies were registered in only six publications, five cases of Hodgkin lymphoma, two of leukemia (one acute myeloid, other chronic lymphoid), and two non specified malignancies.

Six out of eight patients were male, one female, and for one the gender was not mentioned, age ranges from 23 to 70 years. Hodgkin lymphoma and acute leukemia occurred more commonly in acute form patients than in chronic form in contrast with distribution of paracoccidioidomycosis in immunocompetent cases.

Mycosis was known before malignancy in three cases and independently of chemotherapy, four cases presented the acute form and three cases the chronic form of the mycosis. Histopathology showed in six cases poorly organized granulomata with a high number of fungal cells and affected either the same or different organs than that of the malignancies. More severe disease, higher mortality and $40 \%$ of therapeutic failure were observed in lymphoma and acute leukemia in comparison with the evolution of the disease in patients without immunosupression.

\section{Carcinoma and paracoccidioidomycosis}

Considering the total of 97 malignancies associated with 95 patients with paracoccidioidomycosis, carcinoma represented the great majority $(84.5 \%)$ as seen in Table 2. The primary site of carcinoma was respiratory or the digestive tract (Table 2).

In 48 cases with available information, gender distribution showed large predominancy of male, age ranged from 37 to 75 years and the neoplasia affected either the same or neighboring tissues in $64.7 \%$ of the 
Table 2 Type of malignancy in 95 patients with paracoccidioidomycosis and anatomic site
*One patient presenting skin spinocellular and basocellular carcinoma and other patient presenting oat cell esophagus $\mathrm{Ca}$ and mycosis fungoides of the skin

\begin{tabular}{|c|c|}
\hline Hematological malignancies & 14 \\
\hline Hodgkin lymphoma & 07 \\
\hline Leukemia & 05 \\
\hline Acute myeloid & 02 \\
\hline Chronic lymphoid & 02 \\
\hline No reported & 02 \\
\hline Pleomorfic adenoma of lymph node & 01 \\
\hline \multicolumn{2}{|l|}{ Carcinoma } \\
\hline Lung carcinoma & 27 \\
\hline Epidermoid & 07 \\
\hline Undifferentiated & 06 \\
\hline Adenocarcinoma & 02 \\
\hline No reported & 12 \\
\hline Skin Carcinoma & 11 \\
\hline Basocelular & $04 *$ \\
\hline Spinocelular & $04 *$ \\
\hline Mycoses fungoides & $01 * *$ \\
\hline No informed & 02 \\
\hline Oral Carcinoma & 10 \\
\hline Tongue epidermoid & 04 \\
\hline Tongue & 04 \\
\hline Palate epidermoid & 01 \\
\hline Palate & 01 \\
\hline Esophagus & 06 \\
\hline Epidermoid & 03 \\
\hline Spinocelular & 02 \\
\hline No informed & 01 \\
\hline Larynx & 05 \\
\hline Epidermoid & 01 \\
\hline No informed & 04 \\
\hline Stomach & 04 \\
\hline Epidermoid & 03 \\
\hline No informed & 01 \\
\hline Bronchus carcinoma & 04 \\
\hline Epidermoid & 02 \\
\hline Squamous cell & 01 \\
\hline No informed & 01 \\
\hline Bladder carcinoma & 03 \\
\hline Prostate carcinoma & 03 \\
\hline $\begin{array}{l}\text { Kidney, parathyroid, penis, adrenal, colon, cornea, appendix, } \\
\text { Undifferentiated digestive tract Carcinoma }\end{array}$ & 01 each type \\
\hline Metastatic cancer (primary site unknown) & 02 \\
\hline
\end{tabular}

cases (Table 3). Considering 51 cases, paracoccidioidomycosis was diagnosed before the malignancy in $56.9 \%$, after the malignancy in $17.6 \%$ and in $21.6 \%$ both were diagnosed simultaneously. Treatment was made predominantly with sulfamides, and mortality was not attributed to paracoccidioidomycosis in the majority of cases but to infection or malignancy complications. In a patient with oat cell carcinoma 
Table 3 Paracoccidioidomycosis and neoplasia in 51 patients: clinical, epidemiological, and histopathological data

\begin{tabular}{|c|c|c|c|c|}
\hline Age, gender (years old) & Mycosis site & Cancer site & 1st diagnosis & $\begin{array}{l}\text { Reference } \\
\text { number }\end{array}$ \\
\hline 47 male & Respiratory tract & Lung carcinoma & Not mentioned & {$[11]$} \\
\hline 34 male & Oropharynx, larynx lung, liver & Hodgkin lymphoma & Lymphoma & [15] \\
\hline 49 male & Lung & Hodgkin lymphoma & Mycosis & [16] \\
\hline 48 male & Lung & Hodgkin lymphoma & Lymphoma & {$[17]$} \\
\hline 29 male* & Lymph node & Hodgkin lymphoma & Simultaneous & {$[32]$} \\
\hline 50 male & Skin & Lung $\mathrm{Ca}$ & Mycosis & [18] \\
\hline 55 male & Lung & Lung $\mathrm{Ca}$ & Carcinoma & [28] \\
\hline 59 male & Lung & Lung $\mathrm{Ca}$ & Carcinoma & [29] \\
\hline 52 male & Lung & Parathyroid Ca & Simultaneous & {$[30]$} \\
\hline 65 male & Lung, palate & Palate $\mathrm{Ca}$ & Simultaneous & {$[21]$} \\
\hline 57 male & Lung, adrenal & Esophagus $\mathrm{Ca}$ & Carcinoma & {$[31]$} \\
\hline 56 male & Oral, LN, lung & Tongue $\mathrm{Ca}$ & Simultaneous & {$[33]$} \\
\hline 63 male & Oral, LN, lung & Lung $\mathrm{Ca}$ & Mycosis & {$[33]$} \\
\hline 54 male & Oral, LN, lung & Tongue $\mathrm{Ca}$ & Mycosis & {$[26]$} \\
\hline 52 male & Oral, larynx, lung & Larynx $\mathrm{Ca}$ & Mycosis & {$[26]$} \\
\hline 51 male & $\mathrm{LN}$ & Undifferentiated digestive $\mathrm{Ca}$ & Mycosis & [14] \\
\hline 70 male & Pharynx larynx, LN & Chronic lymphoid leukemia & Leukemia & {$[14]$} \\
\hline 55 male & Mucosa, lung & Undifferentiated lung $\mathrm{Ca}$ & Not mentioned & {$[14]$} \\
\hline 55 male & Oral mucosa, LN & Esophagus epidermoid $\mathrm{Ca}$ & Mycosis & {$[14]$} \\
\hline 58 male & Suprarenal & Prostate adenoCa & Carcinoma & {$[14]$} \\
\hline 64 male & Liver, lungs & Bronchus: epidermoid $\mathrm{Ca}$ & Mycosis & {$[14]$} \\
\hline 23 male & Kidney, prostate & Hodgkin lymphoma & Mycosis & {$[14]$} \\
\hline 69 male & Lung & Undifferentiated lung $\mathrm{Ca}$ & Mycosis & [14] \\
\hline 30 female & $\mathrm{LN}$ & Myeloid acute leukemia & Simultaneous & {$[14]$} \\
\hline 56 male & Mucosa, lung & Lung epidermoid $\mathrm{Ca}$ & Carcinoma & {$[14]$} \\
\hline 49 male & Lung & Lung adenoCa & Mycosis & {$[14]$} \\
\hline 70 male & Oral mucosa, lung LN & Rhino pharyngeal $\mathrm{Ca}$ & Mycosis & {$[14]$} \\
\hline 62 male & Mucosa, LN, lung & Bronchus squamous cell $\mathrm{Ca}$ & Mycosis & {$[37]$} \\
\hline 71 male & Prostate & Chronic lymphocytic leukemia & Leukemia & {$[35]$} \\
\hline 66 male & Larynx & Larynx epidermoid carcinoma & Simultaneous & {$[38]$} \\
\hline 52 male & Lung, LN & Tongue: epidermoid Grade II Ca & Mycosis & {$[27]$} \\
\hline 48 male & Larynx, lung & Ca epidermoid: LN metastasis & Mycosis & [27] \\
\hline 53 male & Oral mucosa, lung & $\begin{array}{l}\text { Esophagus oat cell Ca Skin } \\
\text { mycosis fungoides }\end{array}$ & Mycosis & {$[27]$} \\
\hline 43 male & Skin, digestive, larynx & Appendix adenoCa & Mycosis & {$[27]$} \\
\hline 43 male & Skin, mucosa LN, adrenal & $\begin{array}{l}\text { Skin spinocelular and } \\
\text { basocelular grade II } \mathrm{Ca}\end{array}$ & Mycosis & {$[27]$} \\
\hline 43 male & $\mathrm{LN}$ & LN metastasis: $\mathrm{Ca}$ & Simultaneous & {$[27]$} \\
\hline 41 male & $\mathrm{LN}$ & LN: pleomorfic adenoma & Simultaneous & {$[27]$} \\
\hline 68 male & Lung & Cornea: epidermoid intraepithelial $\mathrm{Ca}$ & Mycosis & {$[27]$} \\
\hline 41 female & Digestive, LN & Stomach $\mathrm{Ca}$ & Mycosis & {$[27]$} \\
\hline 54 male & Skin, oropharynx & Esophagus epidermoid grade II Ca & Mycosis & {$[27]$} \\
\hline 46 male & Oropharynx & Skin spinocelular $\mathrm{Ca}$ & Mycosis & {$[27]$} \\
\hline 56 male & Oropharynx, lung & Bronchus epidermoid $\mathrm{Ca}$ & Mycosis & [27] \\
\hline
\end{tabular}


Table 3 continued

\begin{tabular}{|c|c|c|c|c|}
\hline Age, gender (years old) & Mycosis site & Cancer site & 1st diagnosis & $\begin{array}{l}\text { Reference } \\
\text { number }\end{array}$ \\
\hline 68 male & Lung, adrenal & Lung $\mathrm{Ca}$ & Simultaneous & {$[27]$} \\
\hline 20 female & Oropharynx & Amigdala: invasive lymphoma & Simultaneous & [27] \\
\hline 53 male & Lung & Lung epidermoid invasive $\mathrm{Ca}$ & Mycosis & [27] \\
\hline 69 male & Lung & Lung undifferentiated oat cell $\mathrm{Ca}$ & Mycosis & [27] \\
\hline 19 male & $\mathrm{LN}$, liver & Myeloid acute leukemia & Mycosis & [27] \\
\hline 31 male & Oropharynx, lung & Lung oat cell $\mathrm{Ca}$ & Mycosis & {$[27]$} \\
\hline 71 male & Oropharynx & Tongue epidermoid $\mathrm{Ca}$ & Simultaneous & [27] \\
\hline 59 male & Oropharynx & Lympho-histiocitic lymphoma & Mycosis & [27] \\
\hline 60 male & Oropharynx, lung & Bladder Ca & Mycosis & [27] \\
\hline
\end{tabular}

*HIV infection

under chemotherapy without diagnosis of this mycosis [29], necropsy showed suppurative focci in the lungs with a large number of bizarre, multibudding forms of $P$. brasiliensis.

Carcinoma has been associated with chronic form of the mycosis, gender distribution is similar to that seen in chronic form of the disease and age ranges showed predominancy of 50 years or older patients (75.7\%, Table 3).

Carcinoma and mycosis are located in the same anatomic site or neighboring tissue in $64.7 \%$ of patients and more frequently, the mycosis was diagnosed before the malignancy.

Mortality is not attributed to the mycosis except for patients under cytotoxic therapy or dissemination of malignancy.

\section{Comments}

In patients with paracoccidioidomycosis and hematological malignancies, clinical manifestations of the mycosis are more frequently disseminated than localized; appearing before malignancy and independently of chemotherapy. Histopathological findings showed a high number of fungi and poorly organized granulomata. Therapeutic failure was observed in about $40 \%$ of the cases, indicating that an early diagnosis as well as early and efficient intervention is necessary for better therapeutic results.

In contrast, carcinoma might affect immune response depending on its invasive ability and dissemination. Attention to the diseases with similar clinical manifestations is important to avoid misdiagnoses and to indicate as soon as possible the best therapeutic procedure. Cytological and histopathologic examination followed by direct mycological and culture tests are indicated in cases without proven diagnosis of mycosis or malignancy.

In paracoccidioidomycosis, several risk factors predisposing to a malignant transformation of cells could be observed, such as the deficiency of $\mathrm{T}$ cell immunity and of the surveillance against malignancies, chronic antigenic stimulation of the lymphoreticular system and associated factors such as smoking and poor oral hygienic habits.

Higher frequency of carcinoma in chronic form presentation and its localization in the same organs simultaneously or recently invaded by the fungus might be taken in consideration, suggesting that antigenic continuous stimulus and surveillance deficiency against cancer, as seen in malignant transformation of scars, could contribute to malignant transformation of the epithelial or other cells in the inflammatory tissue.

In contrast, the type of malignancies preferentially observed in acute/subacute form patients of this mycosis involves lymphoid tissue and phagocytic mononuclear system. In parallel, in acute/subacute form of the mycosis occurs the strongest disfunction of $\mathrm{T}$ cell immunity, and consequently, cytokines dependent macrophage activation and natural killer surveillance against microorganisms and tumors may be affected.

Although controlled studies were not conclusive about the relationship between paracoccidioidomycosis 
and malignancies, the incidence of cancer in both controlled studies in mycosis population needed to be better examined in prospective studies. In parallel, the major incidence of some malignancies according to the clinical presentation of the disease or by patientś age could be further studied. In effect, carcinoma has not been observed in young patients with acute form disease and was largely observed in chronic multifocal presentation.

Finally, the knowledge of host-parasite interaction at the systemic and tissular levels in patients with cancer and paracoccidioidomycosis remains as a challenge to understand mechanisms involved in malignant transformation aiming to avoid and control such undesirable event.

\section{References}

1. Rabello Filho E. Lupus eritematoso disseminado, blastomicose e epitelioma do lábio superior. An Brás Derm Sif 1933;8:38-9.

2. Oliveira SJ, Mamoni RL, Musatti CC, Papaiordanou PM, Blotta MH. Cytokines and lymphocyte proliferation in juvenile and adult forms of paracoccidioidomycosis: comparison with infected and non-infected controls. Microbes Infect 2002;4:139-44.

3. Peraçoli MTS, Soares AMVC, Mendes RP, Marques SA, Pereira PCM, Rezkallah-Iwasso MT. Studies of natural killer cells in patients with paracoccidioidomycosis. J Med Vet Mycol 1991;29:373-80.

4. Kaminagakura E, Bonan PR, Lopes MA, Almeida OP, Scully C. Cytokeratin expression in pseudoepitheliomatous hyperplasia of oral paracoccidioidomycosis. Med Mycol 2006;44:399-404.

5. Prado FL, Prado R, Gontijo CC, Freitas RM, Pereira MC, Papula IB, Pedroso ER. Lymphoabdominal paracoccidioidomycosis simulating primary neoplasia of the biliary tract. Mycopathologia 2005;160 (1):25-8.

6. Chojlak R, Vieira RA, Lopes A, Silva JC, Godoy CE. Intestinal paracoccidioidomycosis simulating colon cancer. Rev Soc Bras Med Trop 2000;33:309-12.

7. Kaminagakura E, Graber E, de Almeida OP, di Hipolito Junior O, Lopes MA. Oral paracoccidioidomycosis or squamous cell carcinoma? Gen Dent 2004;2 (1):48-50.

8. Payne J, Koopmano CF Jr. Laryngeal carcinoma or is it laryngeal blastomycosis. Laryngoscope 1984;94(5 Pt 1): 608-11.

9. Araujo JC, Werneck L, Cravo MA. South American blastomycosis presenting as a posterior fossa tumour. Case report. J Neurosurg 1978;49:425-8.

10. Teiva NA, Arruda WO, Ramina R, Meneses MS, BlegggiTorres LF, Telles-Filho FO. Paracoccidioidomycosis granuloma simulating posterior fossa tumour. J R Soc Med 1991;84:562-3.
11. Mattos MCFI, Oliveira MLCS. Respiratory cytopathology: paracoccidioidomycosis associated either with tuberculosis or bronchogenic carcinoma. Diagn Cytopathol 1992;8 (2):198-9.

12. Kaminagakura E, Bonan PR, Lopes MA, Almeida OP. Cell proliferation and p53 expression in pseudoepitheliomatous hyperplasia of oral paracoccidioidomycosis. Mycoses 2006;49(5):393-6.

13. Leão RC, Mendes E. Paracoccidioidomycosis, neoplasia and associated infections. Allergol Immunopathol 1980;8:185-8.

14. Conceição YTM. Paracoccidioidomicose e Câncer. Frequência da associação em estudo de necropsias. Dissert. Mestrado, Brazil, São Paulo, Faculdade Medicina Universidade de São Paulo, 1996;102 p.

15. Lacaz CS, Faria JL, Moura RAA. Blastomicose SulAmericana associada à moléstia de Hodgkin. Hospital (Rio de Janeiro) 1948;34(3):313-26.

16. Alterio DL, del Negro G. Blastomicose Sul-Americana associada à moléstia de Hodgkin. Hospital (Rio de Janeiro) 1960;57(1):73-80.

17. Severo LC, Palombini BC, Utz E, Braun SN. Paracoccidioidomicose pulmonar resultante de reativação de lesão quiescente, em paciente imunossuprimido. J Pneumol 1980;6:21-2.

18. Gonzalez HD, Moreira JM, Tchoulamjan A, Urtubey C. Paracoccidiosis y carcinoma de pulmon. Prensa Méd Argent 1957;44:468-72.

19. Machado Filho J, Miranda JL. Considerações relativas à Blastomicose Sul-Americana. Evolução, resultados terapêuticos e moléstias associadas em 384 casos consecutivos. Hospital (Rio de Janeiro) 1961;60(4):375-412.

20. Padilha-Gonçalves A, Adenopatia na micose de Lutz. Rio de Janeiro, 1971. Tese (Cátedra)—Escola de Medicina e Cirurgia do Rio de Janeiro. 234 p.

21. Rapoport A, Santos IC, Andrade Sobrinho J, Faccio CH, Menucelli Jr R. Importância da Blastomicose Sul-Americana (BSA) no diagnóstico diferencial com as neoplasias malignas de cabeça e pescoço. Rev Bras Cir Cab Pesc 1974;1:13-33.

22. Rizzon CFC, Severo LC, Porto NS. Paracoccidioidomicose-Estudo de 82 casos observados em Porto AlegreRS. Rev AMRIGS 1980;24:15-7.

23. Ronquillo TEF. Contribuição ao estudo da paracoccidioidomicose na República do Equador. Rev Pat Trop 1983;12 (3):345-419.

24. Gonçalves AJR, Somogy LA, Braga MP, Pedrosa MC, Carvalho FG, Vieira ARM, Silva MISP, Matos HJ. Paracoccidioidomicose (Blastomicose Sul-American): Experiência de um hospital geral. Arq Bras Med 1984; 58:237-43.

25. Valle ACF, Guimarães RR, Lopes DJ., Capone D. Aspectos radiológicos torácicos na paracoccidioidomicose. Rev Inst Med Trop São Paulo 1992;34:107-15.

26. Tiraboschi IN, Amante HL, Magaro S, Fonseca R, LAsala MB. Paracoccidioidomicosis en un hospital general de área non endêmica. Rev Arg Micol 1992;15:79.

27. Campos SV, Campos AF, Branco MCT, Kono ASG, Freitas VL, Rivitti, EA, Shikanai-Yasuda MA. Estudo retrospectivo dos casos de paracoccidioidomicose e neoplasias do Hospital das Clínicas da Faculdade de Medicina 
da Universidade de São Paulo. Comunicação Congresso da Sociedade Paulista de Infectologia, 2004, Santos, Brazil.

28. Severo LC, Londero AT, Geyer GR, Porto NS. Acute pulmonary paracoccidioidomycosis in an immunossupressed patient. Mycopathologia 1979;68:171-4.

29. Severo LC, Geyer GR, Londero AT, Porto NS. The primary pulmonary lymphnode complex in paracoccidioidomycosis. Mycopathologia 1979;67:115-8.

30. Gonçalves AJR, Guerra S, Jesus PLL. Paracoccidioidomicose aguda escavada associada a carcinoma de paratiróide. F Méd (Br) 1980;81(6):623-6.

31. Esper FE, Moraes DM, Santos EP, Rocha A. Associação de megaesôfago chagásico com carcinoma de esôfago fistulizado para a aorta, megaduodeno e blastomicose sul americana. Relato de um caso Rev Col Bras Cir 1985;12 (1):29-33.

32. Pedro RJ, Aoki FH, Boccato RSBS, Branchini MLM, Gonçalves Jr FL, Papiordanou PMO, Ramos MC. Paracoccidioidomicose e infecção pelo vírus da imunodeficiência humana. Rev Inst Med Trop São Paulo 1989; $31: 119-25$.
33. Shikanai-Yasuda MA, Anteghini HJ, Arruda EAG, Benard G, Duarte MIS, Barone AA, Amato Neto V. Adenocarcinoma e paracoccidioidomicose. Rev Arg Micol 1992;15:67.

34. Goldenfum R, Fernando FB, Gramacho K, Pasa A, Severo LC. Paracocccidioidomicose e neoplasia: análise de 14 casos. J Pneumol 1992;18(Suppl 1):19.

35. Melo CR, Melo IS, Cerski CI. Paracoccidioidomycosis: report of 2 cases mimicking squamous cell carcinoma. Br J Urol 1992;70:329-30.

36. Marques SA, Shikanai-Yasuda MA. Paracoccidioidomycosis associated with immunosuppression, Aids and Câncer. In: Franco M, Lacaz CS, Restrepo-Moreno A, Del Negro G, editors. Paracoccidioidomycosis. 1st ed. Boca Raton: CRC Press; 1994. p. 393-405.

37. Meneses-Garcia A, Mosqueda-Taylor A, Morales de la Luz R, Rivera LMRG. Paracoccidioidomycosis: report of 2 cases mimicking squamous cell carcinoma. Oral Surg Oral Med Oral Pathol Oral Radiol Endod 2002;94:609-13.

38. Maymo Argañaraz M, Luque AG, Tosello ME, Perez J. Paracoccidioidomycosis and larynx carcinoma. Mycoses 2003;46(5-6):229-32. 